\title{
Kızılötesi Kurutucuda Nane Bitkisinin Optimum Kurutma Sıcaklığının Belirlenmesi
}

\author{
Özgür DEMİ** \\ Muş Alparslan Üniversitesi, Mühendislik-Mimarlık Fakültesi, Muş \\ (ORCID: 0000-0001-6889-7940)
}

\begin{abstract}
$\ddot{\mathbf{O} z}$
$\mathrm{Bu}$ çalışmada, tasarım ve imalatı yapılan kızılötesi 1sıtıcılı kurutma fırınında, nane bitkisi farklı sıcaklıklarda kurutularak optimum kurutma sıcaklığı belirlenmiştir. Kurutma firınında kurutma işlemine tabi tutulan nane yapraklar1 $50^{\circ} \mathrm{C}, 60^{\circ} \mathrm{C}, 70^{\circ} \mathrm{C}, 80^{\circ} \mathrm{C}$ ve $90^{\circ} \mathrm{C}$ sicaklıklarda kurutulmuştur. Kurutma süreleri özgül enerji tüketimleri, yaş ve kuru esasa göre nem miktarları ortaya koyulmuştur. Nane yapraklarının kurutma işlemleri başlangıç nem oranı 8,12 g su/ g kuru madde iken bu oranın 0,094545 g su/ g kuru madde ye kadar düştüğü görülmüştür. Özgül enerji tüketimi ise $21,10 \mathrm{MJ} / \mathrm{kg}$ ile $52,08 \mathrm{MJ} / \mathrm{kg}$ arasında bulunmuştur. Tüm deneylerde elde edilen kuru ürün kaliteleri farklılık gösterirken renk, aroma, koku ve enerji tüketimi bütün olarak değerlendirildiğinde optimum kurutma sıcaklığının $70^{\circ} \mathrm{C}$ olduğu ortaya koyulmuştur. Bu sicaklığın altında yapılan kurutma işlemlerinde aroma ve koku artmakta, lakin enerji tüketimi de artmaktadır. $70^{\circ} \mathrm{C}$ üzeri sıcaklıktaki kurutma işlemleri incelendiğinde aroma ve koku azalırken enerji tüketimi de düşmektedir.
\end{abstract}

Anahtar kelimeler: Kızılötesi kurutucu, Nane, Kurutma.

\section{Optimum Drying Temperature of Mint Plant in Infrared Dryer}

\begin{abstract}
In this study, mint plants were dried at different temperatures to determine the optimum drying temperature in infrared heat dryers. The mint leaves were dried at $50{ }^{\circ} \mathrm{C}, 60{ }^{\circ} \mathrm{C}, 70{ }^{\circ} \mathrm{C}, 80{ }^{\circ} \mathrm{C}$, and $90{ }^{\circ} \mathrm{C}$ in the drying oven. Specific energy consumption of leaves during drying time and their moisture contents according to dry and wet basis were determined. Whereas the initial moisture contents of leaves were $8.12 \mathrm{~g}$ water $/ \mathrm{g}$ dry matter, this value decreased to $0.094545 \mathrm{~g}$ water / $\mathrm{g}$ dry matter after drying process. With regard to specific energy consumption, it was between $21.10 \mathrm{MJ} / \mathrm{kg}$ and $52.08 \mathrm{MJ} / \mathrm{kg}$. Whereas the dry product quality obtained in all experiments varied, all other parameters including the color, aroma, odor, and energy consumption were optimum at $70^{\circ} \mathrm{C}$. The drying processes below this degree causes increase of aroma and smell in parallel with energy consumption. On the other hand, at higher temperatures from $70{ }^{\circ} \mathrm{C}$ smell, aroma and energy consumption decrease.
\end{abstract}

Keywords: Infrared drying, Mint, Dry.

\section{Giriş}

Gıda maddelerinin uzun süre korunması için uygulanan birçok yöntem vardır. Gıdalara uygulanan kurutma işlemi en eski ve en çok kabul gören muhafaza yöntemidir. Gıda ürünlerinin kontrollü bir şekilde kurutulması çok büyük bir öneme sahiptir. Gıda maddeleri yetiştirilebildikleri aylar dışında da kullanılabilmesi veya iklim, toprak şartları yetiştirilmesine uygun olmayan bölgelere ulaştırılabilmesi veya ihtiyaç anında kullanılabilmek üzere muhafaza edilmektedir. Gıda muhafaza yöntemi olarak kurutmanın tercih edilmesinin sebebi, mikrobiyolojik ve enzimsel değişimlerin önüne geçmesi veya azaltmasıdır [1]. Kullanım açısından en yaygın kurutma yöntemi olan güneş altında yaygıda kurutma, kalite ve hijyen noktasında olumsuz sonuçlar vermektedir. Her enlem boylamda bulunan yerleşim

*Sorumlu yazar: o.demir@alparslan.edu.tr

Geliş Tarihi: 01.04.2019, Kabul Tarihi: 26.07.2019 
bölgesinin sahip olduğu güneş ışınımının kurutma için yeterli olmayışı, kurutulan ürünün yaygıda toz, böcek, mikroorganizma vb. etkenlere maruz kalması, kurutma süresine bağlı olarak fermantasyon riski gibi önemli etkenler göz önüne alındığında güneşaltında kurutma zamanla uzaklaşılan bir yöntem haline gelmiştir [2]. Hijyen, kalite vb. problemler ortaya koyulmaya başlandıkça daha profesyonel kurutma sistemlerinin gerekliliği ortaya çıkmıştır. Teknik kurutma önem kazanmaya başlamıştır [3]. Gıdalar için kurutucu tasarımı yapılırken kurutulacak gıda için kurutma gereksinimlerini iyi tespit etmek gerekir [4]. Nane (Mentha spicata L.) yenilebilen, menthol içeriği sebebi ile de tıbbi bir aromatik bitki olarak tanımlanabilmektedir. Mutfak kültürümüze yaş ve kuru yaprak olarak yerleşen nane bitkisi tükettiğimiz birçok yemek, salata, meze vb içerisinde çokça kullanılmaktadır. Nane bitkisi tıbbi etkisi vesilesi ile ilaç sektöründe, hoş kokusu sebebi ile kimya sanayinde, güzel ve keskin aroması nedeni ile gıda ve içki sanayisinde kullanımı yaygındır [5]. Nane limon ve limon kabuğu ile demlenerek kullanıldığında üst solunum ve sindirim rahatsızlıklarına iyi gelmektedir, ayrıca kuru hali baharat çeşidi olarak kullanılmaktadır [6] Nane bitkisi içeriğinde bulunan su miktarı göz önüne alındığında bozulmadan uzun süre saklanması mümkün olmayan bir bitki olarak karşımıza çıkmaktadır. Uzun süre muhafazası için kurutma işlemine tabi tutulması en geçerli yöntem olarak karşımıza çıkmaktadır. Gıdalar için birçok kurutma yöntemi kullanılmaktadır. Kızıl ötesi 1sıtıcı ile kurutma yöntemi enerji tüketimi açısından birçok yönteme göre avantajlı olup çalışmamızda bu yöntem kullanılmıştır. Kocabıyık ve Demirtürk [7], $1080 \mathrm{~W} / \mathrm{m}^{2}$ yoğunlukta infrared radyasyonla farklı hava hızlarında nane yaprağı kurutmuş hava hızı artışının kurutma süresini (64dk-180dk arası) olumsuz etkilediği bilgisini ortaya koymuşlardır. Çalışmanın sonuçları incelendiğinde 37.04 ile $106.58 \mathrm{MJ} / \mathrm{kg}$ özgül enerji tüketimi olduğu bildirilmiştir. Doymaz [8], 35-60 ${ }^{\circ} \mathrm{C}$ sıcaklıklarda nane yaprağı kurutmuşlardı ve sıcaklık artışının kurutma süresinde azalmaya sebep olduğunu ortaya koymuştur. Park vd. [9], nane kurutma parametrelerinin değerlendirilmesi üzerine yaptığı çalışmada nane bitkisini konveksiyonel sıcak havalı bir kurutucuda kurutmuşlardır. Nane yaprakları ve kızılötesi kurutma ile ilgili kurutma çalışmaları incelenmiş ve tespit edilen üstünlüklerinden dolayı kurutma sistemi 1sı kaynağı tercihi olarak kızıl ötesi 1şınım kullanımının doğru olacağı birçok çalışmada irdelenmiştir [10-13].

\section{Teorik Analiz}

Çalışmada deneysel metot kullanılmış olup hesaplamalar için faydalanılan eşitlikler ve eşitliklere ilişkin gösterimler aşă̆ıda verilmiştir.

Ürünlerin kuru esasa göre hesaplanan nemliliği $\mathrm{MR}_{\mathrm{K}}$;

$M R_{K}=\frac{m_{Y}-m_{K}}{m_{K}}$

Ürünlerde yaş esasa göre hesaplanan nemliliği MRY;

$$
\begin{aligned}
& M R_{Y} \frac{m_{Y}-m_{K}}{m_{Y}} \\
& N o=\frac{m_{Y}-m_{K}}{M o-m_{K}}
\end{aligned}
$$

Özgül enerji tüketimi kurutulan birim kütle ürün için harcanan enerji miktarı olup Es;

$$
\mathrm{Es}=\frac{E t}{W r}
$$

Özgül nem çekme oranı üründen $1 \mathrm{~kg}$ suyu uzaklaştırmak için harcanan enerjidir SMER;

$$
S M E R=\frac{m_{s u}}{Q_{h}}
$$

Burada; 
$m_{Y}$ : Yaş ürün kütlesi $(\mathrm{g})$

$m_{K}$ : Kuru ürün kütlesi $(\mathrm{g})$

$M o$ :İlk kütle (g)

$\mathrm{N}_{\mathrm{O}}$ : Nem Oranı

Es: Özgül enerji tüketimi (MJ/kg),

Et: Toplam enerji (MJ),

Wr: Örnekten uzaklaştırılan suyun kütlesi $(\mathrm{kg})$

$\mathrm{m}_{\mathrm{su}}$ : Üründen çekilen su kütlesi, $\mathrm{kg} \mathrm{s}^{-1}$

$\mathrm{Q}_{\mathrm{h}}$ : Kurutucuda harcanan enerji, kJ

\section{Kurutma Sistemi}

Kurutma fırını, özellikleri bakımından deneysel çalışma için uygun şekilde tasarlanmış ve imalatı yapılmıştır. İmalatı yapılan kurutma firınında 2 adet $100 \mathrm{~W}$ halojen 1sıtıcı kullanılmıştır. Kurutma havası sıcaklığg için analog termostat kullanılmıştır. Loadcell den gelen veri 1şığında sistemi kapatma işlemi veri toplama cihazı özelliği olarak bulunan röle sayesinde sağlanmıştır.

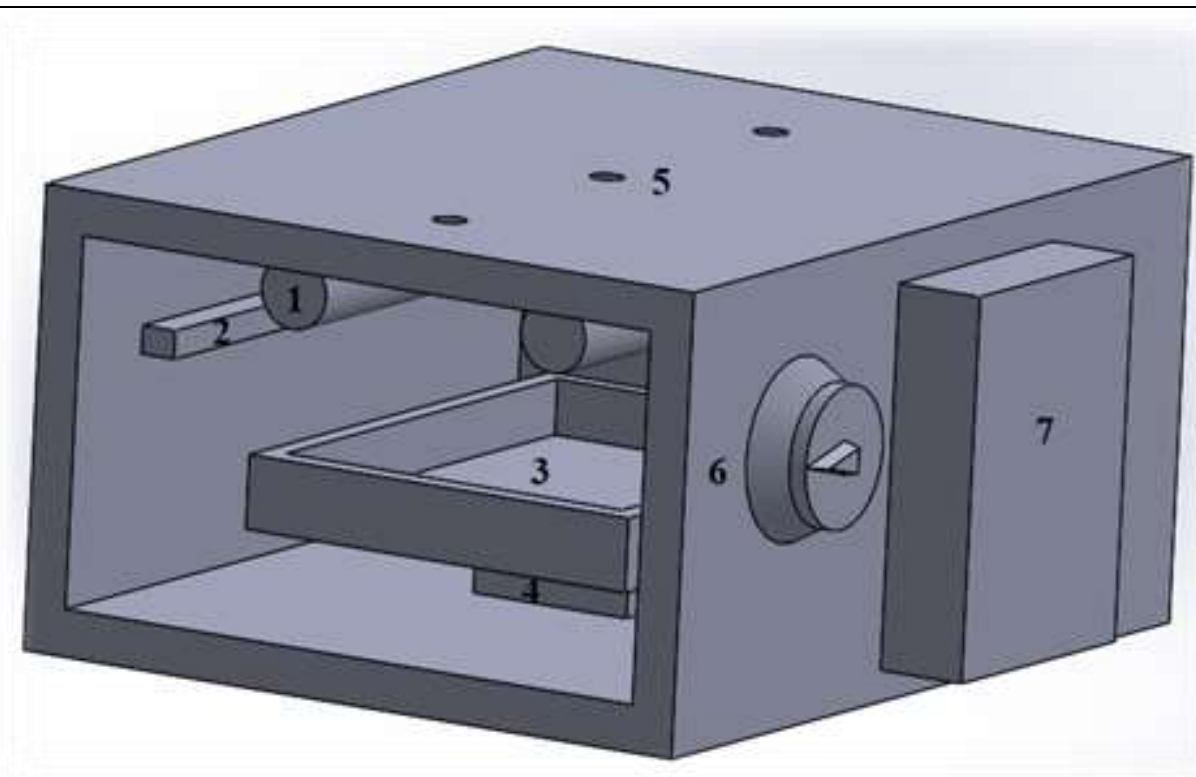

1-Kızılötesi 1sıtıc12-Sicaklık ve Nem Sensörü

3-Ürün sepeti 4-Load cell 5- Nem Tahliye 6-Termostat 7-24V Sensör besleme Trafosu

Şekil 1. Kurutma Fırını Bileşenleri

Kurutucu sistem Şekil 1'de gösterilen bölüm ve bileşenlerden oluşmaktadır. Sistemde kullanılan ölçüm alet ve cihazları Tablo 1'de verilmiştir. Deneyler esnasında load-cell ile anlık kütle ölçümü yapılmış olup son üç değer aynı ölçülene kadar kurutmaya devam edilmiştir. Sıcaklık ve bağıl nem değerleri, hem ortam havası hem de kurutucu iç hacmi için veri toplama ve izleme cihazı ile kayıt edilmiştir. Ürünlerin başlangıç ve deney sonu kütleleri yükssek hassasiyetli dijital terazi ile teyit edilmiştir. Kurutucu hacmi $0,3375 \mathrm{~m}^{3}$ olup kurutma tepsisi $0,0169 \mathrm{~m}^{2}$ dir. Kurutulacak ürünler delikli tepsiye dağınık ve olabildiğince eşit yükseklikte serilmiştir. Deneylerde kullanılan ürün kütlesi $5 \mathrm{~g}$ $( \pm 0,1)$ olarak belirlenmiştir. Kurutma firınına $295,8 \mathrm{~g} / \mathrm{m}^{2}$ kurutulacak ürün yüklemesi yapılmıştır. Kurutucuda hava hareketi $0,2 \mathrm{~m} / \mathrm{s}$ altında olup cebri bir sistem kullanılmamıştır. Ürünün tam kuru ağırlığı belirlenmesi işlemi için etüv firını kullanılmıştır. Tam kuru ağırlık belirlenirken ön hazırlıktan geçirilen $100 \mathrm{~g}$ ' lık ürün $105^{\circ} \mathrm{C}$ sıcaklıkta ön ısıtması yapılmış etüv firınında son üç kütle ölçüm değeri için aynı değer gözlemlenene kadar kurutulmuştur. Kurutulan ürün kütlesinin 100 g' dan 10,5 g' a düştüğü görülmüştür. Tüm ölçü aletleri kalibrasyonu ve hata analizi yapılarak deneysel çalışmada kullanılmıştır. 
Tablo 1. Kullanılan ölçü aletleri ve özellikleri

\begin{tabular}{|c|c|c|c|}
\hline $\begin{array}{c}\text { Kullanılan } \\
\text { Cihaz }\end{array}$ & Marka Model & Teknik Özellikleri & Hata Analizi \\
\hline Dijital tartı & $\begin{array}{l}\text { Desis } \\
\text { Ehb } 300\end{array}$ & $\begin{array}{ll}300 \mathrm{~g} \text { kapasiteli } & 0,001 \mathrm{~g} \\
\text { hassasiyetli }\end{array}$ & $\pm 0,012 \mathrm{~g}$ \\
\hline $\begin{array}{l}\text { Sicaklık ve bağıl } \\
\text { nem ölçüm cihazı }\end{array}$ & $\begin{array}{l}\text { Blitz-sens } \\
\text { TH2-3W-U }\end{array}$ & $\begin{array}{l}\text { Sicaklık Ölçüm Aralığı: - } \\
30 . .+70^{\circ} \mathrm{C} \text { Nem Ölçüm Aralığı: } \\
0 . . \% 100 \text { Rh Sinyal Çıkışı: 4..20 } \\
\mathrm{mA} / 0-10 \mathrm{~V}\end{array}$ & $\begin{array}{l} \pm 0,04^{\circ} \mathrm{C} \\
\pm \% 0,02\end{array}$ \\
\hline $\begin{array}{l}\text { Veri Toplama ve } \\
\text { İzleme Cihaz }\end{array}$ & $\begin{array}{l}\text { Graphtec } \\
\text { GL } 240\end{array}$ & 10 Kanallı & \\
\hline Etüv & Kenton GX40 & 40lt PID kontrollü $\pm 5-50^{\circ} \mathrm{C}$ & $\% 2$ \\
\hline Yük Hücresi & Celtron Lps & $0,6 \mathrm{~kg}$, alüminyum, tek nokta, & $\pm 0,024$ \\
\hline $\begin{array}{l}\text { Yük Hücresi } \\
\text { Transmitteri }\end{array}$ & Esit TR03 & 0-10V çıkış, 1 kanal röle çıkış1 & 0,03 \\
\hline
\end{tabular}

Deneylere başlamadan önce nane yaprakları dallarından koparılmış, ön hazırlık işleminden geçirilmiştir. Oda sıcaklığından kaynaklı nem kaybına maruz kalmaması için hemen kurutma işlemine başlanmıştır. İlk olarak tam kuru ağırlık için $105^{\circ} \mathrm{C}$ 'de etüv firınında kurutulan nane yapraklarının içeriğindeki su oranı belirlenmiştir. Deneyler sırasında sıcaklık, bağıl nem ve kütle değişimi dakikalık olarak takip edilmiş olup kurutma süreleri ortaya koyulmuştur (Şekil 2). Kurutma işlemi süresince harcanan enerji Wh cinsinden ölçülmüş olup Şekil 3'te verilmiştir.

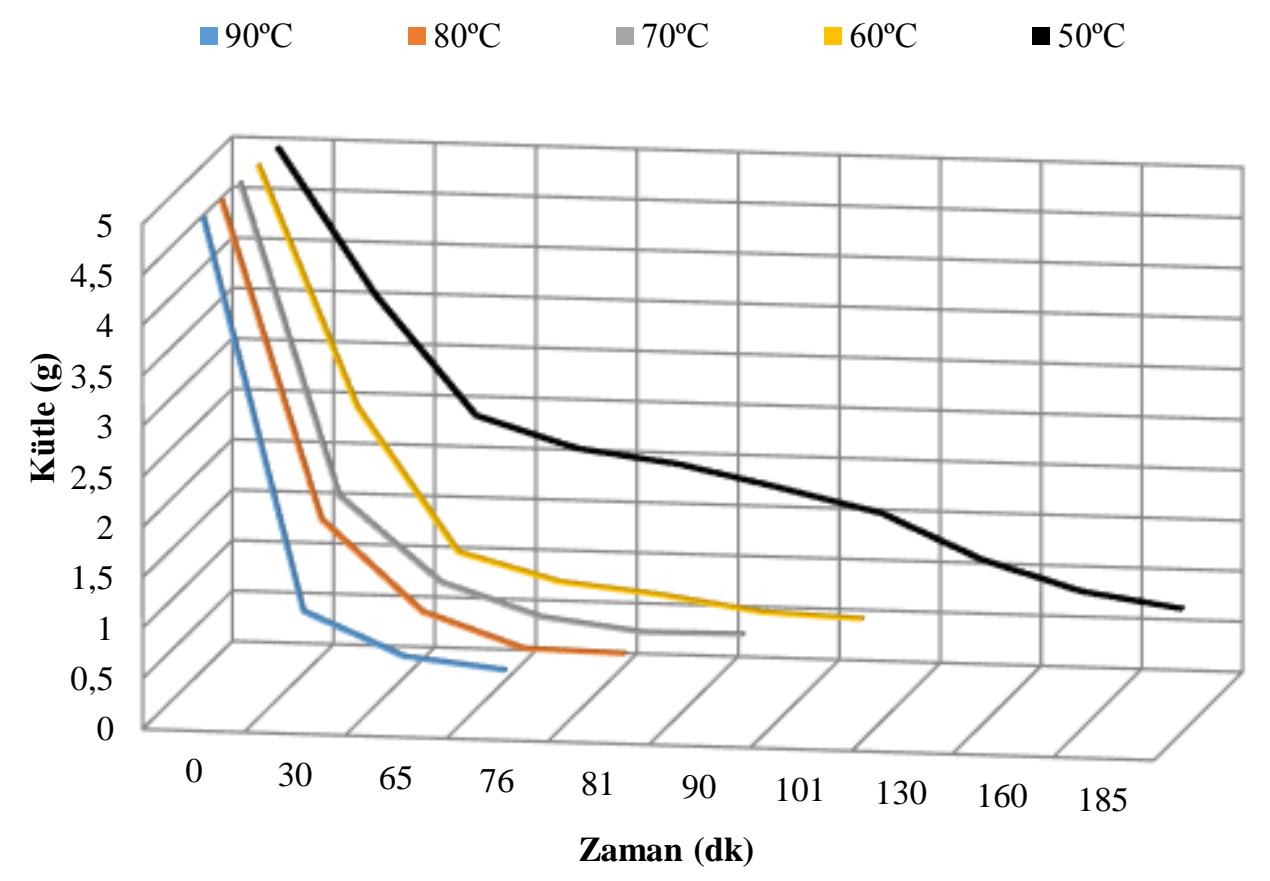

Şekil 2. Nanenin değişik sıcaklıklarda kızılötesi kurutulmasında Kütle-Zaman değişimi

Şekil 3 incelendiğinde tüketilen enerji miktarı kurutma süresi ile ters orantılı olduğu, kurutma havası sıcaklığı arttıkça tüketimin düştüğ̈̈ görülmektedir. 


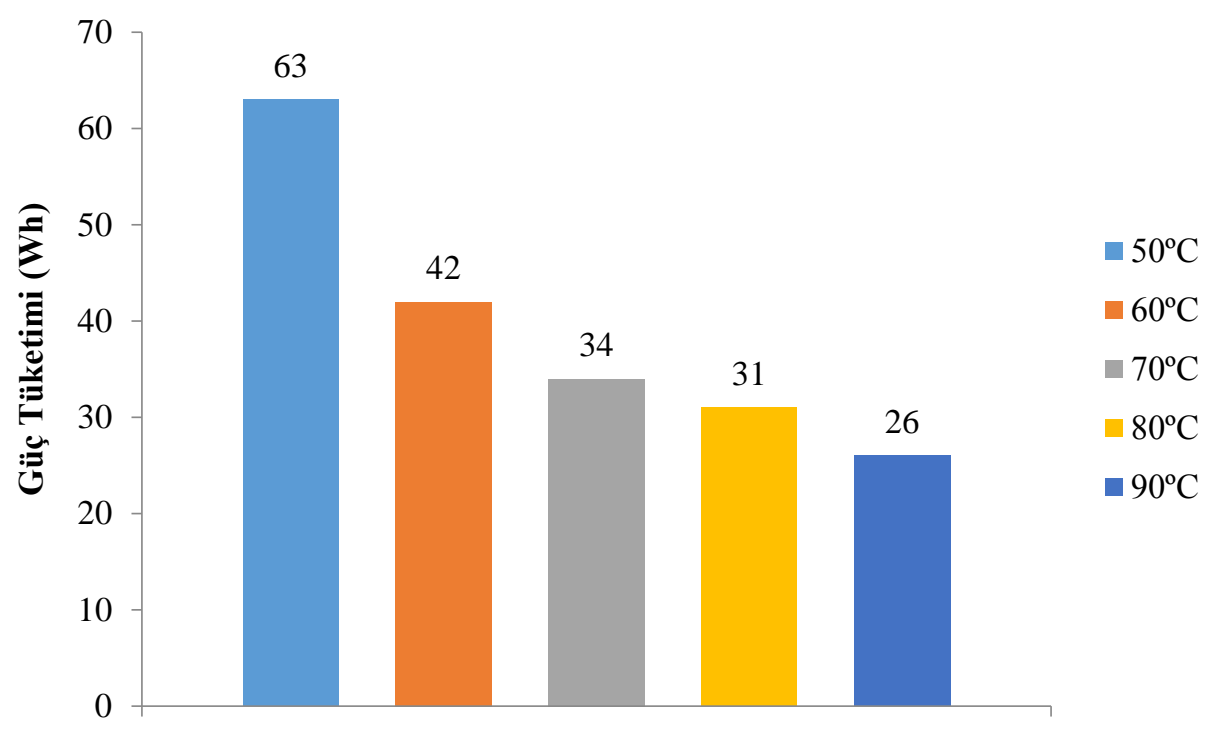

Şekil 3. Nanenin değişik sıcaklıklarda kızılötesi kurutulmasında tüketilen enerji miktarları

Özgül enerji tüketimi Eşitlik 4 yardımı ile her bir kurutma sıcaklığı için hesaplanmış ve Şekil 4 'te verilmiştir. Özgül enerji tüketimi kurutma sıcaklığı ile doğru orantılı olduğu ortaya koyulmuştur.

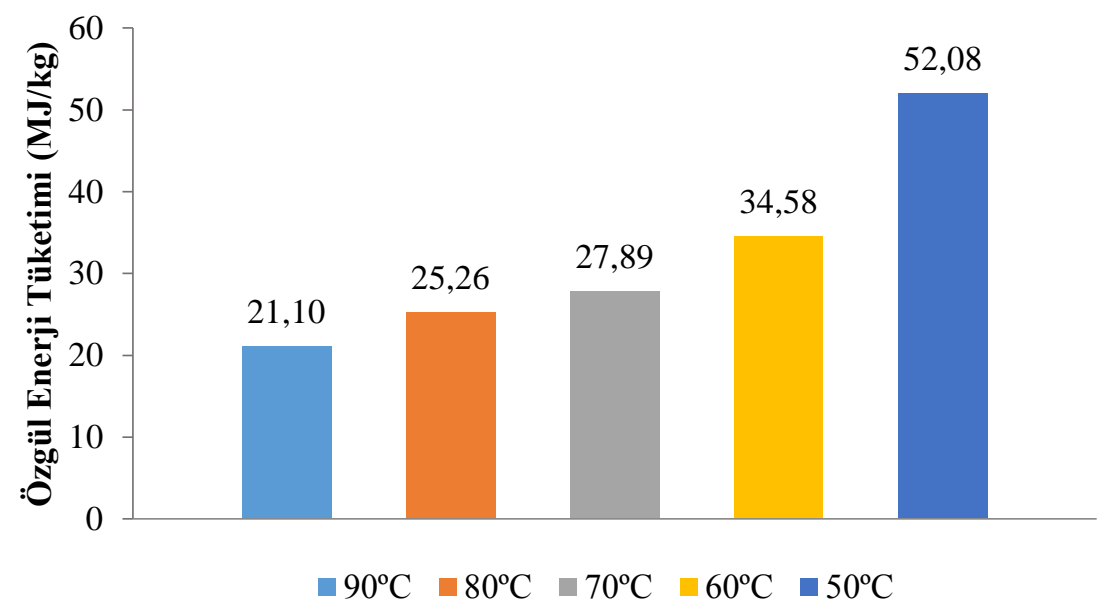

Şekil 4. Nanenin değişik sıcaklıklarda kızılötesi kurutulmasında özgül enerji tüketimi

Yapılan her deney için kurutma süresince ürün içinde kalan su miktarı Eşitlik 2 yardımı ile hesaplanmış yaş esasa göre hesaplanmış olup Şekil 5'te verilmiştir. 


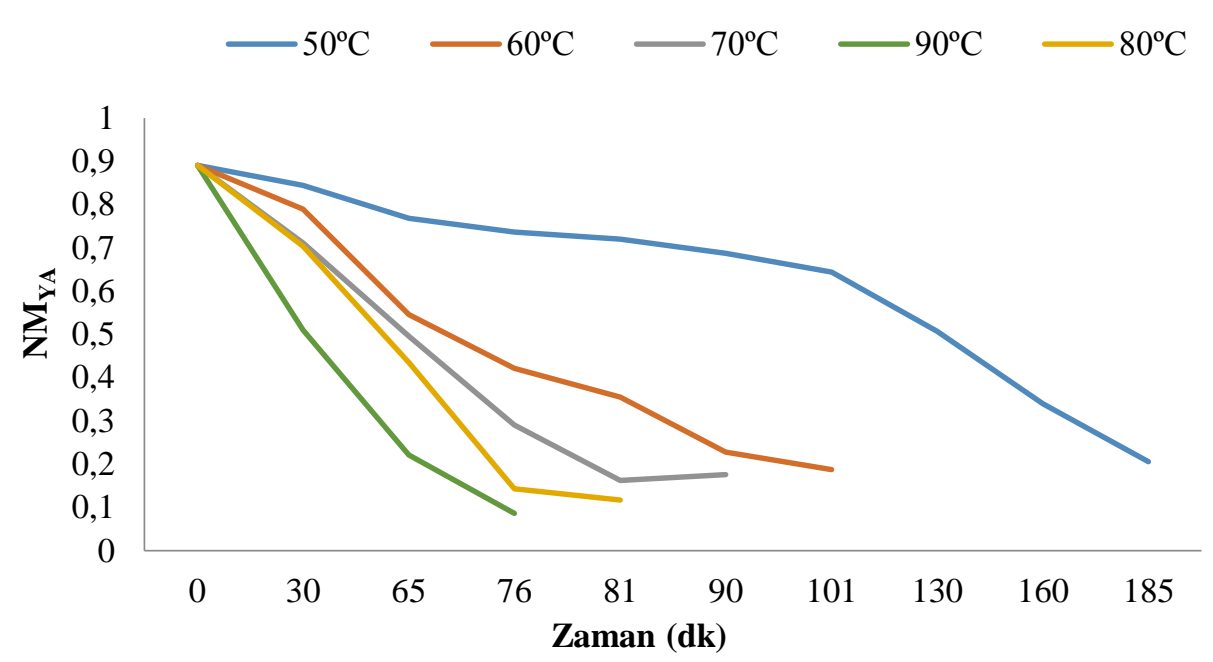

Şekil 3.5. Kurutma esnasında zamanla yaş esasa göre nemliliğin değişimi

\section{Sonuç ve Öneriler}

Çalışmada nane bitkisi kurutmak amacı ile halojen lambalı bir kurutucu tasarlanmış ve imalatı yapılmıştır. Ön hazırlıktan geçirilen ve dalından kopartılan nane yaprakları $50^{\circ} \mathrm{C}, 60^{\circ} \mathrm{C}, 70^{\circ} \mathrm{C}, 80^{\circ} \mathrm{C}$, ve $90^{\circ} \mathrm{C}$ sıcaklıklarda kurutulmuştur. Her bir kurutma işlemi için kurutma işlem süreci takip edilmiştir. Kurutma işlemleri sonucu ürünlerin nem miktarları 8,12g su/ $\mathrm{g}$ kuru madde değerinden $0,259928 \mathrm{~g}$ su/ $\mathrm{g}$ kuru madde, $0,230677 \mathrm{~g} \mathrm{su} / \mathrm{g}$ kuru madde, $0,214318 \mathrm{~g} \mathrm{su} / \mathrm{g}$ kuru madde, $0,133477 \mathrm{~g}$ su/g kuru madde, $0,094545 \mathrm{~g} \mathrm{su} / \mathrm{g}$ kuru madde değerlerine kadar düşürülmüştür. Kurutma süreleri yine sırasıyla 185 dakika,101 dakika,90 dakika,81 dakika,76 dakika olarak belirlenmiştir. Alınan veriler 1şı̆̆ında yapılan hesaplamalar sonucu özgül enerji tüketimleri sirasıyla 52,08MJ/kg, 34,58 MJ/kg, 27,89 MJ/kg, 25,76 $\mathrm{MJ} / \mathrm{kg}, 21,10 \mathrm{MJ} / \mathrm{kg}$ olarak bulunmuştur. Deney sonuçlarına göre eitlik 5 ile hesaplanan SMER değerleri sırasıyla $0,42 \mathrm{~kg}$ buharlaş̧ırılan nem/ kWh, 0,48 kg buharlaştııılan nem/ kWh, 0,52 kg buharlaştırılan $\mathrm{nem} / \mathrm{kWh}, 0,57 \mathrm{~kg}$ buharlaştırılan nem/ $\mathrm{kWh}$ ve $0,59 \mathrm{~kg}$ buharlaştırılan nem/ $\mathrm{kWh}$ olarak hesaplanmıştır Hesaplanan değerler literatürde Kocabıyık H. Ve Demirtürk B.S.(2008) in ulaştı̆̆ 37,04 ile 106,58 $\mathrm{MJ} / \mathrm{kg}$ özgül enerji tüketimi değerleri ile karşılaştırıldığın da verimli bir kurutma sistemi ortaya koyulduğu görülmektedir. Deneyler sonucu elde edilen ürünlerde duyusal analiz yapılmıştır. Yapılan analiz sonucu optimum kurutma sıcakl 1 ğ $170^{\circ} \mathrm{C}$ olarak belirlenmiştir. $70^{\circ} \mathrm{C}$ altındaki sıcaklıklarda yapılan kurutma işlemi neticesinde, ürün içeriğinde kalan nem miktarının nispeten fazla olduğu görülmüştür. $70^{\circ} \mathrm{C}$ üzeri sıcaklıklarda yapılan deneylerde enerji tüketimi ve süresi aşırı düşmekte lakin elde edilen kuru ürünlerde yapısal bozulmalar gözlemlenmiştir. $70^{\circ} \mathrm{C}$ kurutma havası sıcaklığının üzerine çıkıldıkça üründe bölgesel olarak yeşilden, açık kahve rengine dönüşen renk değişimi olduğu tespit edilmiştir. Bu durum bize yüksek sıcaklıklarda yapılan kurutma işleminin, üründe yanmalara yol açtığını göstermiştir. İlerleyen çalışmalarda $70^{\circ} \mathrm{C}$ kurutma sıcaklığında, farklı hava hızlarında kurutma işlemi yapılması ve optimum kurutma havası hızının belirlenmesi düşünülmektedir.

\section{Kaynaklar}

[1] Heybeli N., Ertekin C. 2007. Elma Dilimlerinin İnce Tabaka Halinde Kuruma Karakteristiği. Tarım Makinaları Bilimi Dergisi, 3 (3). 179-187.

[2] Cemeroğlu B. 2004. Meyve Sebze İşleme Teknolojisi. 2. Cilt. ISBN 975-98578- 2-0, Ankara.

[3] Doymaz İ. 2003. Convective Air Drying Characteristics of Thin Layer Carrots. Journal of Food Engineering, 61: 359-364.

[4] Ertekin C., Yaldız O. 2001. Patlıcan kurutmada kurumanın çeşitli modeller ile açıklanması. Tarımsal Mekanizasyon 20. Ulusal Kongresi Bildiri Kitabı, 399-404, Şanlıurfa.

[5] Özbek B., Dadalı G. 2007. Thin-layer drying characteristics and modelling of mint leaves undergoing microwave treatment. Journal of Food Engineering, 83: 541-549. 
[6] Türkan Ş., Malyer H., Özaydın S., Tümen G. 2006. Ordu ili ve çevresinde yetişen bazı bitkilerin etnobotanik özellikleri. Süleyman Demirel Üniversitesi Fen Bilimleri Enstitüsü Dergisi,10 (2).

[7] Kocabıyık H., Demirtürk B.S. 2008. Nane Yapraklarının İnfrared Radyasyonla Kurutulması. Tekirdağ Ziraat Fakültesi Dergisi, 5 (3): 239-246

[8] Doymaz İ. 2005. Sun Drying of Figs: an Experimental Study. Journal of Food Engineering, 71: 403-407.

[9] Park K.J., Vohnikova Z., Brod F.P.R. 2002. Evaluation of drying parameters and desorption isotherms of garden mint leaves (Mentha crispa L). Journal of Food Engineering, 51: 193-199.

[10] Fasina O. 2003. Infrared heating of food and agricultural materials. ASAE Paper No.036219 St. Joseph, Mich.: ASAE.

[11] Strumillo C., Kudra F.T. 1986. Drying: Principles, Applications and Design. Gordon and Breach Science Publishers, New York.

[12] Lewis M.J. 1996. Physical Properties of Food and Food Processing Systems, Woodhead Publishing Limited, Cambridge, England.

[13] Hebbar H., Vishwanathan K.H., Ramesh M.N. 2004. Devolopment of combined infrared and hat air dryer for vegetables. Journal of Food Engineering, 65: 557-563. 